Provided for non-commercial research and education use. Not for reproduction, distribution or commercial use.

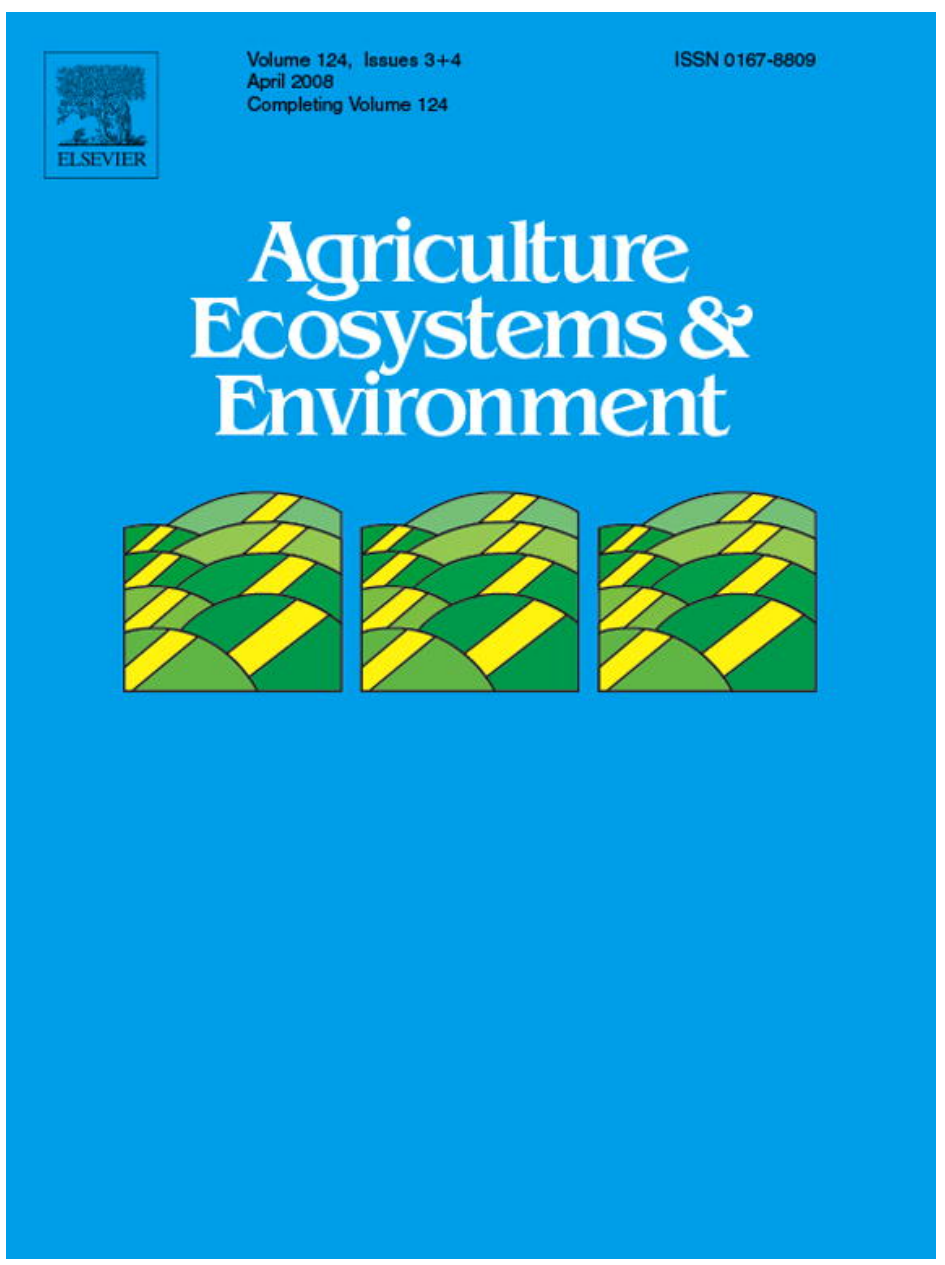

This article was published in an Elsevier journal. The attached copy

is furnished to the author for non-commercial research and education use, including for instruction at the author's institution, sharing with colleagues and providing to institution administration.

Other uses, including reproduction and distribution, or selling or licensing copies, or posting to personal, institutional or third party websites are prohibited.

In most cases authors are permitted to post their version of the article (e.g. in Word or Tex form) to their personal website or institutional repository. Authors requiring further information regarding Elsevier's archiving and manuscript policies are encouraged to visit: 


\title{
Soil structure, organic matter and earthworm activity in a comparison of cropping systems with contrasting tillage, rotations, fertilizer levels and manure use
}

\author{
Hugh Riley ${ }^{\mathrm{a}, *}$, Reidun Pommeresche ${ }^{\mathrm{b}}$, Ragnar Eltun ${ }^{\mathrm{a}}$, \\ Sissel Hansen ${ }^{\text {b }}$, Audun Korsaeth ${ }^{\mathrm{a}}$ \\ ${ }^{a}$ Norwegian Institute for Agricultural and Environmental Research, Arable Crops Division, NO-2849 Kapp, Norway \\ ${ }^{\mathrm{b}}$ Norwegian Institute for Agricultural and Environmental Research, Organic Food and Farming Division, NO-6630 Tingvoll Norway
}

Received 2 July 2007; received in revised form 13 November 2007; accepted 16 November 2007

Available online 15 January 2008

\begin{abstract}
In order to assess long-term effects on productivity, environmental impacts and soil fertility of contrasting farming practices, six cropping systems, ranging from conventional arable without livestock to organic mixed dairy farming with few arable crops, have been compared since 1989 on a loam soil. A decline in soil structure quality was found in a conventional arable system with annual ploughing with no rotational grass. This system had higher bulk density and mean aggregate size than other systems, and lower levels of plant available water and aggregate stability. Opposite trends were related to the proportion of grass leys in the other systems and to their levels of soil organic matter. The latter declined markedly over 15 years in the conventional arable system, and there were smaller declines in most other systems. In an arable system without ploughing, but with rotary tillage in spring, organic matter was maintained and high structural stability was found. This system had high bulk density, but the proportion of small aggregates equalled that found in systems with ley. There were overall increases in earthworm density (84\%), earthworm biomass (80\%) and the density of earthworm channels (132\%) in the topsoil between 1994 and 2004. Most of these increases were found in systems with 1-3 years of ley in the 4-year rotation. Low values of all earthworm parameters, and only minor changes over the period studied, were found in two non-organic arable systems without ley, indicating high pressure on soil fauna. Lower earthworm activity was found in the non-organic arable system with reduced tillage as compared to the non-organic arable system with annual ploughing. Thus, 50\% leys in the rotation appeared desirable for the maintenance of satisfactory soil structure and earthworm activity. Though the deterioration of soil structure in the conventional arable system was not extreme, as the soil was well structured initially, the results may have implications for the sustainability of stockless arable systems on soils with a less favourable initial structure.
\end{abstract}

(C) 2007 Elsevier B.V. All rights reserved.

Keywords: Aggregates; Arable; A. caliginosa; Bulk density; Ley; L. terrestris; Porosity; Stability; Soil quality

\section{Introduction}

The role of crop rotations in determining soil structure and crop growth conditions has been recognised as being of prime importance for sustainable crop production (Ball et al., 2005). In organic cropping, the management of grass swards is of particular interest for the maintenance of soil structure (Ball et al., 2007). The objective of the present

\footnotetext{
* Corresponding author. Tel.: +47 40622630.

E-mail address: hugh.riley@bioforsk.no (H. Riley).
}

study was to study the long-term effects of a gradient of cropping systems (CS) on soil structure, soil organic matter and earthworm activity. The cropping systems ranged from conventional arable without livestock, to organic mixed dairy farming dominated by leys. The study shows the combined effects of crop rotation, tillage regime, pesticide use, fertilization intensity and manure use in a long-term field experiment established in 1989 at Apelsvoll in SE Norway (Eltun, 1994) on a loam soil with a high initial soil organic matter (SOM) level. Arable-ley rotations had been followed previously at the site for many years. 
Several studies in Scandinavia have confirmed that SOM levels decline after the transition from cropping systems with a high proportion of leys to arable systems with annual ploughing (Christensen, 1990; Uhlen, 1991; Kirchmann et al., 1994; Cuvardic et al., 2004). Rather rapid changes are often seen initially, but it is often considered that new equilibrium levels will be reached over time. The switch to dominantly arable rotations occurred in Norway up to 40-50 years ago. Nevertheless, a recent survey of SOM in this region (Riley and Bakkegard, 2006) has suggested that levels are still declining quite markedly, at a rate similar to that found recently in England and Wales (Webb et al., 2001). The long-term consequences of declining SOM for the quality of soil structure are matters of both concern and debate.

Organic matter content is generally regarded as one of the key indicators of soil quality (Gregorich et al., 1994; Schjønning et al., 2004), but the existence of a critical threshold has been questioned (Carter, 2002; Loveland and Webb, 2003). Many features of favourable soil structure, such as stability, friability and moisture retention, may be affected by SOM, but the influence of other processes such as compaction by traffic, tillage, the use of manure and the type of rotation and crop residue management are also important.

Another key indicator of soil quality is earthworm activity, which is important for improving and maintaining soil fertility, soil structure and aggregate stability (Edwards and Lofty, 1977; Clements et al., 1991; Marinissen, 1994). The experimentally induced absence of earthworms in a grass sward was found to increase soil bulk density and shear strength and to greatly reduce soil organic matter, soil moisture and infiltration rate (Clements et al., 1991). Systems with grass and clover in the rotation often host higher biomass and numbers of earthworms compared with all-arable systems (Edwards and Lofty, 1977; Schmidt et al., 2003). Organic cropping systems have shown higher earthworm biomass and density than conventional systems (Mäder et al., 2002), but this is not always so (Scullion et al., 2002). Animal manure provides food and increases the biomass of earthworms (Andersen, 1979), but slurry may be toxic in the short term (Curry, 1976). Similarly, ammonium-based inorganic fertilizers may also be harmful to earthworms, especially in sandy soils (Lofs-Holmin, 1983; Hansen and Engelstad, 1999). Mineral fertilizers may have positive effect on earthworms by increasing the amount of plant biomass, thereby increasing their food supply (Edwards and Lofty, 1982), but pH must be regulated to avoid negative effects of acidifying fertilizers (Ma et al., 1990).

Ploughing of established grassland increases earthworm populations, but continuous cultivation usually lowers them (Lee, 1985). Positive effects on earthworms are often found under reduced tillage systems (Zicsi, 1969; Lee, 1985; Ekeberg, 1992). The choice of tillage method affects the relative abundance of earthworm species. No tillage/direct drilling favours night crawlers (Lumbricus terrestris), whilst ploughing favours field worms (Aporrectodea caliginosa) (Chan, 2001). Field worms and pink worms (Aporrectodea rosea) are endogeic species, living mainly in the topsoil, eating soil and comminuted organic matter within the soil. They construct many temporary channels. Night crawlers are large, aneic species, living for years in the same permanent vertical burrows (0-200 cm depth), eating organic matter found either on the surface or in the soil. Earthworm channels in the deeper soil layers $(>25 \mathrm{~cm})$ are less disrupted by ploughing and thus indicate a more permanent effect of the cropping system, than do the density and biomass of earthworms found in the topsoil.

Pesticides used in conventional arable and fodder production may have negative effects on, for example, reproduction or growth, that affect earthworm populations in the long term. Most fungicides have low direct effects, with the exceptions of the carbamate-based fungicides, which all are very toxic to earthworms, as are also insecticides such as the organophospates and most of the carbamate-based compounds (Edwards and Bohlen, 1992). Although all pesticides are tested for their environmental impact before approval, acute terrestrial toxicity tests are conducted solely on compost earthworms (Eisenia fetida) with low sensitivity. The most dominant earthworm in agricultural soil, the field worm (Aporrectodea caliginosa), is known to be more sensitive towards chemicals than the compost worm $(E$. fetida) (Spurgeon et al., 2000; Frampton et al., 2006). Longterm effects are much less documented. Cold climatic conditions prolong the persistence of pesticides in countries like Norway, whilst freezing and thawing events make the leaching and biodegradation of the pesticides much more unpredictable than in more stable climates (Rotich et al., 2004; Stenrød et al., 2005, 2007). This may result in effects on earthworm populations that are not considered in the pesticide approval procedure.

\section{Materials and methods}

\subsection{Site description and cropping systems}

The cropping systems experiment was established in 1989 and is located on Apelsvoll farm of the Norwegian Institute for Agricultural and Environmental Research, Arable Crops Division, $60^{\circ} 42^{\prime} \mathrm{N}, 10^{\circ} 51^{\prime} \mathrm{E}$, altitude $250 \mathrm{~m}$. The region has a humid continental climate, with mean annual precipitation of $600 \mathrm{~mm}$ and mean annual temperature of 3.6 and $12{ }^{\circ} \mathrm{C}$ in the growing season. The experiment covers an area of ca. 3 ha, on loam soil with imperfect or poor natural drainage. The respective major soil groups are classified as Aquic Fragiudept and Typic Epiaquept (Soil Survey Staff, 1998), Endostagnic Cambisol and Haplic Stagnosol (FAO, 1998) and Gleyed Melanic Brunisol and Orthic humic gleysol (CSSC, 1998). Topsoil texture is morainic loam $(47 \pm 4 \%$ sand, $35 \pm 2 \%$ silt, $18 \pm 2 \%$ clay $)$, with some gravel and frequent stones. At the start of the trial 


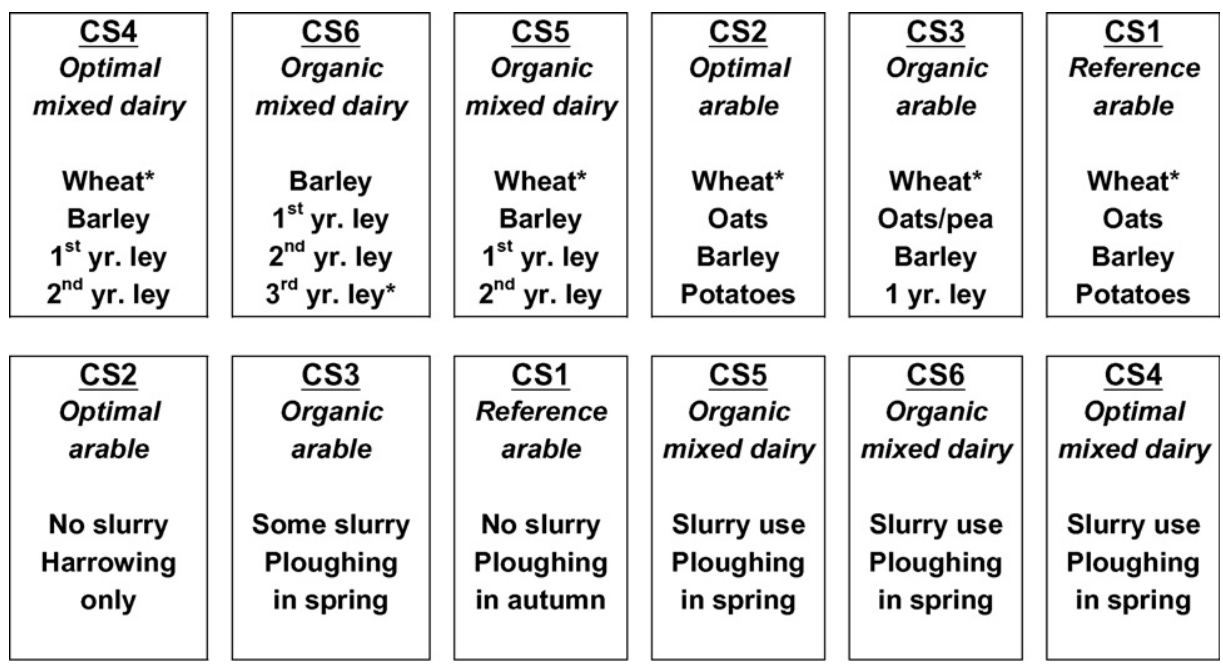

Fig. 1. Internal distribution in field and description of six contrasting cropping systems (CS1-CS6) on twelve $60 \times 30$ blocks (two replicate blocks per system). The four crops grown in each system every year since 1999 are shown in the upper row (a four-year crop rotation). Management features related to slurry use and ploughing are shown in the lower row. Slurry = wet-composted cattle slurry, 6.4\% DM, with 26, 20 and $28 \mathrm{Mg} \mathrm{ha}^{-1}$ year $^{-1}$ in systems 4,5 and 6 for the period 2000-2003 and 9, 36, 23 and $28 \mathrm{Mg} \mathrm{ha}^{-1}$ year $^{-1}$ for 1990-1999. *Earthworms were sampled under these crops in 1999 and 2004.

in 1989 , topsoil organic matter was $4.5 \pm 0.7 \%$. Details on the variability of soil physical and chemical properties at the site may be found in Riley and Eltun (1994).

The experimental area is divided into twelve $30 \mathrm{~m} \times 60 \mathrm{~m}$ blocks (model farms), two of which are used for each of three arable cropping systems and two for each of three mixed dairy systems (Fig. 1). Each block comprises four $15 \mathrm{~m} \times 30 \mathrm{~m}$ plots, individually drained at $1 \mathrm{~m}$ depth with $7.5 \mathrm{~m}$ drain spacing, on which all of the arable and/or fodder crops in the rotation of each cropping system are grown each year. The blocks are separated by $7.5 \mathrm{~m}$ grass borders. The arable crops include spring cereals (wheat Triticum aestivum L., barley Hordeum vulgare L., oats Avena sativa L.) and potatoes (Solanum tuberosum) and oats with peas (Pisum sativum L.). Fodder crops include grassclover leys (timothy Phleum pratense L. and meadow fescue Festuca pratensis Huds. grasses with red clover Trifolium pratense L.) and, until 1999, swedes (Brassica napus L.). Catch crops of Italian ryegrass (Lolium multiflorum Lam.) are grown as appropriate in all but the reference conventional arable system (1).

The management of the six cropping systems is summarized in Fig. 1. Some changes in the crops included in the rotations were made after the first 10 years (Korsæth et al., 2001), as were some minor changes in tillage and fertilizer levels. The main features, such as manure use and the incidence of leys, have nevertheless been almost unaltered since 1990. Cropping systems CS1-CS3 represent arable production that is typical for this region of Norway, whilst CS4-CS6 represent fodder production typical of mixed dairy farming, with 2-3 ley years (grass-clover mix) in the rotation. In CS1, which is considered as a reference system that reflects arable practices that are common when little attention is paid to non-point source losses of nutrients from agriculture, the soil is ploughed annually, usually in autumn, though spring ploughing was practiced from 1995 to 1999 . CS2 incorporates perceived system improvements related to the risk of nutrient loss. In this system, ploughing is replaced by rotor harrowing in spring and ryegrass catch crops are grown each year. In the remainder, the soil is ploughed in spring in all but the ley years.

All systems have a 4-year crop rotation, with each crop present every year. Besides leys, the crops grown are mainly spring cereals, but with $25 \%$ potatoes in CS1 and CS2. Leys are undersown in cereals. Animal manure (cattle slurry) is used in CS4, CS5 and CS6. Mineral fertilizers ( $\mathrm{N}$ in $\mathrm{NH}_{4} \mathrm{NO}_{3}$ ) are applied in CS1, CS2 and CS4. Less mineral fertilizer and pesticides are used in CS2 than in CS1. No mineral fertilizer or pesticides are used in the organic systems (CS3, CS5 and CS6). Soil acidity has been buffered with lime when necessary. More details on crop rotation and management are given in Korsaeth and Eltun (2000), Korsæth et al. (2001) and Eltun et al. (2002).

\subsection{Sampling and methods of analysis}

\subsubsection{Soil structure}

Analyses of bulk density, air-filled porosity, air permeability and moisture retention were made on samples taken to $75 \mathrm{~cm}$ depth from four soil profiles per system in autumn 1988 (Riley and Eltun, 1994). The 24 profiles were distributed in a $30 \mathrm{~m} \times 35 \mathrm{~m}$ grid. In autumn 2003 , the topsoil of these profiles was re-sampled by taking three undisturbed $100 \mathrm{~cm}^{3}$ soil cores at depths of both 5-9 and 19$23 \mathrm{~cm}$, and analysed as in 1988. Air filled porosity and water retention were measured using Soil Moisture ceramic plate and membrane equipment at matric potentials of 10,100 and $150 \mathrm{kPa}$. Equivalent pore sizes at these potentials were assumed to be 30,3 and $0.2 \mu \mathrm{m}^{2}$, respectively. Air permeability was measured at $10 \mathrm{kPa}$ matric potential using 
the method of Green and Fordham (1975). Bulk density was measured after drying samples at $105^{\circ} \mathrm{C}$. SOM was measured by ignition-loss at $550{ }^{\circ} \mathrm{C}$, with the use of the following site-specific correction for clay content (Riley and Eltun, 1994):

$$
\begin{aligned}
\mathrm{SOM}= & 0.81 * \text { ignition-loss }(\%)-0.038 * \operatorname{clay}(\%)-0.7 \\
& \left(R^{2}=0.97, n=240\right)
\end{aligned}
$$

The relative degree of compactness was calculated by dividing field measured bulk density by the standard bulk density that may be attained under a static pressure of $200 \mathrm{~Pa}$ (Håkansson and Lipiec, 2000). In the present case, the standard bulk density (SBD) was predicted from the following relationship, found for Norwegian soils by Riley (1988):

$$
\begin{aligned}
\mathrm{SBD}= & 1.751-0.032 * \text { ignition- } \operatorname{loss}(\%)-0.0032 * \\
& \operatorname{silt}(\%)+0.0065 * \operatorname{gravel}(\%)+0.0029 * \operatorname{clay}(\%) \\
& \left(R^{2}=0.79, n=29\right)
\end{aligned}
$$

For the above variables, the 2003 results were assessed both directly as measured values, and indirectly as the changes that had taken place since 1988. In addition, 24 loose samples were taken by spade in 2003 from the top $15 \mathrm{~cm}$ of soil, for measurements of aggregate size by sieving of air-dried samples over meshes of 2, 6, 10 and $20 \mathrm{~mm}$ and of the stability of 2-6 mm aggregates by simulated rainfall at 1 bar pressure on a $2 \mathrm{~mm}$ sieve, using the simulated rainfall method of Njøs (1967). The mean weight diameter of aggregates was calculated as described by van Bavel (1949), assuming a maximum aggregate size of $35 \mathrm{~mm}$, in order to provide a simple index of the aggregate size distribution.

Statistical analyses (ANOVA and $t$-tests) were performed with MSTAT and Minitab. Error bars in figures are based on four observations, comprising two replicate blocks and two parareplicates within blocks. The latter were spaced $35 \mathrm{~m}$ apart, equal to the distance between the mid-point of different blocks, and thus considered therefore as independent observations from a soil variability point of view.

\subsubsection{Earthworm activity}

Earthworm data were sampled in each cropping system block (two replicates) in autumn 1994 and autumn 2004. Samples were taken from plots (within the blocks) with spring wheat in all cases except system CS6 in 2004, in which the crop was third year ley (see Fig. 1). Worms were hand-sorted from three soil cubes $(50 \mathrm{~cm} \times 50 \mathrm{~cm} \times 25 \mathrm{~cm}$ depth) at each plot, and the density of juvenile and adult worms (ED) and the dead, fresh biomass (EB) were recorded. The density of earthworm channels (CHAN) was recorded in the horizontal plane at $25 \mathrm{~cm}$ depth under each soil cube. The species were identified according to Sims and Gerard (1999). Error bars in figures are based on six observations, comprising two replicate blocks and three parareplicates within blocks. Unless otherwise noted, the results presented are from the 2004 data set.

The effects of systems on earthworm biomass, earthworm density and channel density were tested with ANOVA and the Ryan's test using the general linear model procedure in SAS (SAS Institute Inc., 1987). Contrasts were used to compare the systems with and without cattle manure and the systems with and without grass-clover ley. $t$-Tests were used to compare the mean values for 2004 and 1994.

\section{Results}

\subsection{Soil structure}

\subsubsection{Bulk density, porosity and organic matter content}

The differences between depth horizons in these parameters were mostly small and non-significant. For the sake of clarity, only mean topsoil results are presented here (Table 1).

Mean bulk density was highest in 2003, and had increased significantly since 1988, under the intensive arable management system (CS1). It was lowest in 2003 in the system with most leys (CS6). Total porosity had decreased significantly between 1988 and 2004 in CS1. There were also smaller, but non-significant, declines in porosity in the other two arable systems.

SOM was lowest, and had declined most in CS1, while it was highest, and had remained unchanged since 1988, in the system with reduced tillage (CS2). Small declines in SOM had taken place in the other systems, despite the presence of leys.

The difference in total porosity, from the system with the highest to that with the lowest values, was about 4\%. By comparison with the effects often found in compaction studies, this represents a considerable range. The ranking of systems with respect to porosity showed a positive relationship with the incidence of leys within the rotation, although there was rather high variability in some systems (Fig. 2). The amount of readily available plant moisture (pore size 3-30 $\mu \mathrm{m})$ had declined significantly $(p=0.008)$ more in CS1 than in all other systems, and both this and to some extent more strongly bound available moisture (pore size $0.2-3 \mu \mathrm{m}$ ), showed positive relationships with SOM (Fig. 3). The volume of air-filled pores, on the other hand, correlated poorly with SOM, though the absolute values were greatest in the system with most leys (CS6). Air permeability was in all cases higher in 2003 than that measured in 1988 (data not shown). In most cases it was more than $10 \mu \mathrm{m}^{2}$, which is well above the level that may be considered critically low (Riley, 1988).

The optimal value for crop growth of the relative degree of compactness has been found to lie within the range of 85$87 \%$, depending on weather conditions (Håkansson and Lipiec, 2000). Soil that is too compact impedes root growth and may have aeration problems, whilst soil that is too loose 
Table 1

Topsoil (0-30 cm) means ( \pm S.E.) of soil bulk density, total porosity and soil organic matter measured in 1988 and 2003 and the changes, with paired $t$-tests, that had occurred in these parameters

\begin{tabular}{|c|c|c|c|c|c|c|c|}
\hline & & \multicolumn{6}{|l|}{ System } \\
\hline & & $\mathrm{CS} 1$ & $\mathrm{CS} 2$ & $\mathrm{CS} 3$ & CS4 & CS5 & CS6 \\
\hline Bulk density $\left(\mathrm{Mg} \mathrm{m}^{-3}\right)$ & $\begin{array}{l}1988 \\
2003 \\
\text { Change } \\
t \text {-Test }\end{array}$ & $\begin{array}{l}1.29 \pm 0.03 \\
1.43 \pm 0.04 \\
+0.14 \\
p=0.005\end{array}$ & $\begin{array}{l}1.37 \pm 0.05 \\
1.40 \pm 0.02 \\
+0.03 \\
\text { n.s. }\end{array}$ & $\begin{array}{l}1.33 \pm 0.03 \\
1.38 \pm 0.04 \\
+0.05 \\
\text { n.s. }\end{array}$ & $\begin{array}{l}1.37 \pm 0.05 \\
1.34 \pm 0.01 \\
-0.03 \\
\text { n.s. }\end{array}$ & $\begin{array}{l}1.34 \pm 0.04 \\
1.36 \pm 0.02 \\
+0.02 \\
\text { n.s. }\end{array}$ & $\begin{array}{l}1.31 \pm 0.02 \\
1.29 \pm 0.02 \\
-0.02 \\
\text { n.s. }\end{array}$ \\
\hline Porosity (\%) & $\begin{array}{l}1988 \\
2003 \\
\text { Change } \\
t \text {-Test }\end{array}$ & $\begin{array}{l}49.1 \pm 1.1 \\
44.8 \pm 1.3 \\
-4.3 \\
p=0.003\end{array}$ & $\begin{array}{l}46.7 \pm 1.9 \\
45.0 \pm 0.8 \\
-1.7 \\
\text { n.s. }\end{array}$ & $\begin{array}{l}49.0 \pm 0.5 \\
46.8 \pm 1.3 \\
-2.2 \\
\text { n.s. }\end{array}$ & $\begin{array}{l}45.8 \pm 1.4 \\
47.0 \pm 0.4 \\
+1.2 \\
\text { n.s. }\end{array}$ & $\begin{array}{l}48.4 \pm 1.2 \\
47.5 \pm 0.7 \\
-0.9 \\
\text { n.s. }\end{array}$ & $\begin{array}{l}48.7 \pm 0.5 \\
48.9 \pm 0.5 \\
+0.2 \\
\text { n.s. }\end{array}$ \\
\hline $\operatorname{SOM}(\%)$ & $\begin{array}{l}1988 \\
2003 \\
\text { Change } \\
t \text {-Test }\end{array}$ & $\begin{array}{l}4.62 \pm 0.39 \\
3.06 \pm 0.39 \\
-1.56 \\
p<0.001\end{array}$ & $\begin{array}{l}4.13 \pm 0.55 \\
4.12 \pm 0.14 \\
-0.01 \\
\text { n.s. }\end{array}$ & $\begin{array}{l}4.52 \pm 0.21 \\
3.87 \pm 0.31 \\
-0.65 \\
p=0.057\end{array}$ & $\begin{array}{l}4.11 \pm 0.35 \\
4.02 \pm 0.11 \\
-0.09 \\
\text { n.s. }\end{array}$ & $\begin{array}{l}4.67 \pm 0.28 \\
3.83 \pm 0.25 \\
-0.84 \\
p<0.001\end{array}$ & $\begin{array}{l}4.55 \pm 0.17 \\
3.90 \pm 0.13 \\
-0.65 \\
p=0.016\end{array}$ \\
\hline
\end{tabular}

Description of cropping systems (see also Fig. 1 for further details): CS1, reference arable system with 0\% leys in the crop rotation; CS2, optimal arable system with $0 \%$ leys in the crop rotation; CS3, organic arable system with $25 \%$ leys in the crop rotation; CS4, optimal mixed dairy system with 50\% leys in the crop rotation; CS5, organic mixed dairy system with $50 \%$ leys in the crop rotation; CS6, organic mixed dairy system with $75 \%$ leys in the crop rotation.

impedes water and nutrient uptake by plants. Fig. 4 shows that the soil tended towards over-compactness in all three arable systems (CS1-CS3), whereas it was in the optimum range in systems with a high proportion of leys and slurry application (CS4-CS6). Despite high variability in this parameter, particularly in CS3, the differences between systems were close to significance $(p=0.06)$.

\subsubsection{Aggregate size and stability}

There was a marked shift in aggregate size distribution towards more cloddy soil with decreasing incidence of leys in the cropping system (Fig. 5). The mean aggregate weight diameter ranged from $10 \mathrm{~mm}$ in CS6 (75\% ley) to $18 \mathrm{~mm}$ in CS1 (0\% ley). This trend showed low significance $(p=0.1)$, due to high variability in the three larger size classes. Statistically significant differences $(p<0.05)$ were, however, found between systems in the two smaller classes. The

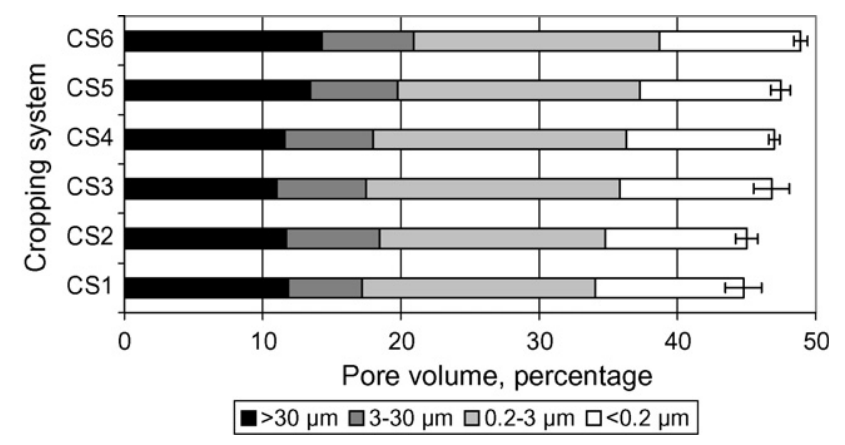

Fig. 2. Pore size distribution measured in 2003 in the topsoil of six cropping systems (error bars are \pm standard errors of the total porosity). Description of cropping systems: CS1, reference arable system with $0 \%$ leys in the crop rotation; CS2, optimal arable system with $0 \%$ leys in the crop rotation; CS3, organic arable system with $25 \%$ leys in the crop rotation; CS4, optimal mixed dairy system with $50 \%$ leys in the crop rotation; CS5, organic mixed dairy system with $50 \%$ leys in the crop rotation; CS6, organic mixed dairy system with $75 \%$ leys in the crop rotation. proportion of aggregates in these two classes increased roughly in relation to the incidence of leys in the rotation, except in the case of the arable system with reduced tillage (CS2). In the latter case, the amount of small aggregates was equally as high as in the rotations with at least $50 \%$ leys. This suggests that it is possible to obtain a satisfactory seedbed without ploughing.

Aggregate stability, measured for the class size $2-6 \mathrm{~mm}$ which normally dominates in the seedbed in spring, showed very low variability within systems, and highly significant differences $(p<0.001)$ between the systems could therefore be seen (Fig. 6). For this parameter also, it was the arable system with annual ploughing (CS1) that differed most from the others, with more than $25 \%$ reduction in stability in relation to those that were most stable. The systems with the highest aggregate stability (almost 90\%) were that with $75 \%$ ley (CS6) and the arable system with

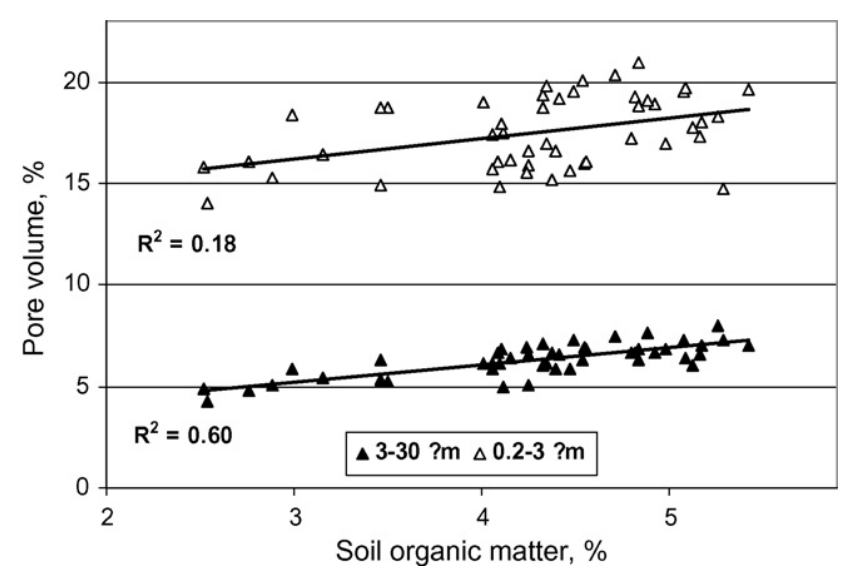

Fig. 3. Relationships between soil organic matter and the retention of capacities for readily available water $(3-30 \mu \mathrm{m})$ and more strongly held available water $(0.2-3 \mu \mathrm{m})$. 


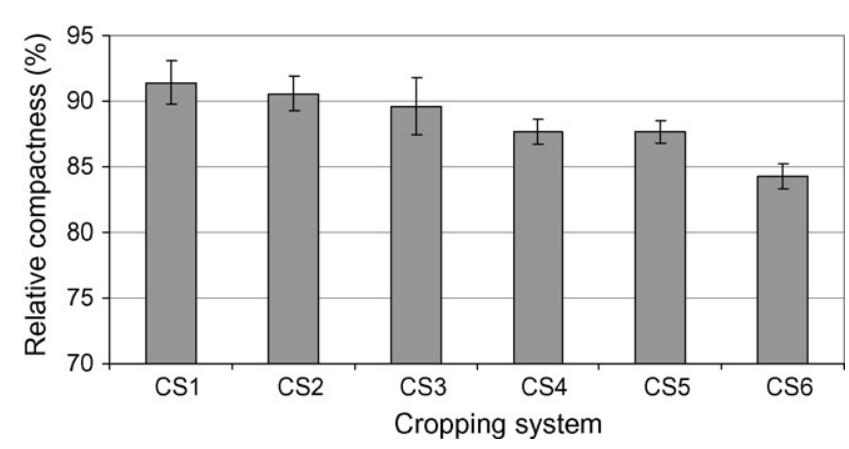

Fig. 4. Relative degree of compactness (BD as \% of standard compaction at $200 \mathrm{kPa}$ ) measured in the topsoil of six cropping systems (error bars are \pm standard errors). Description of cropping systems as in Figs. 1 and 2.

reduced tillage $(\mathrm{CS} 2)$. In the latter system, straw residues have been retained in the soil since 1993 . The stability in the organic system with $25 \%$ ley (CS3) was as high as in the system with $50 \%$ ley (CS4), while the organic system with $50 \%$ ley (CS5) had higher stability than the latter.

\subsection{Earthworm activity}

Earthworm density (ED), pooled over all six cropping systems, had increased by 84\% from 1994 to 2004, but the increases were only significant in the organic CS3 and CS5 (Fig. 7). The optimal mixed dairy system with 50\% ley (CS4) had the highest earthworm density in 2004 (275 worms $\mathrm{m}^{-2}$ ), but this was not significantly higher than that in the organic arable system with only $25 \%$ ley (CS3). The two non-organic arable systems (CS1 and CS2) had the lowest densities, 66 and 27 worms $\mathrm{m}^{-2}$, respectively, and the level was almost unaltered between 1994 and 2004.

Earthworm biomass (EB), pooled over all six systems, had increased by $80 \%$ from 1994 to 2004. Significant increases in biomass since 1994 were seen in the system with organic arable cropping (CS3), and in the optimal (CS4) and organic mixed dairy (CS5) systems (Fig. 8), and these had the highest levels in 2004 (mean $108 \mathrm{~g} \mathrm{~m}^{-2}$ ). Lowest earthworm biomass in 2004 (mean $33 \mathrm{~g} \mathrm{~m}^{-2}$ ), with only minor changes since 1994, was found in the two non-organic arable systems (CS1 and CS2).

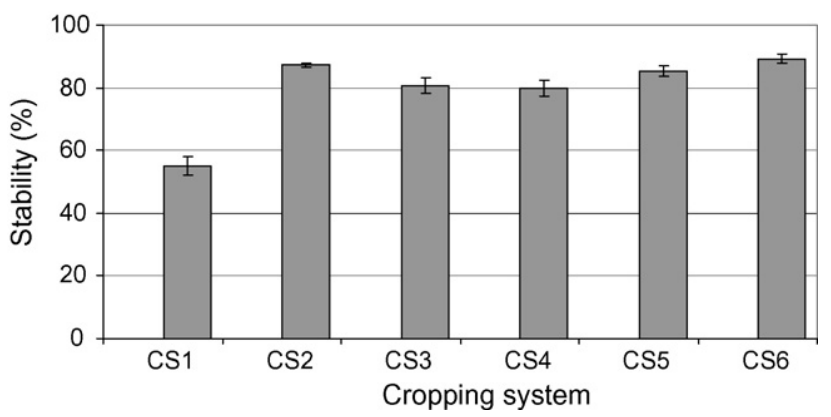

Fig. 6. Stability of $2-6 \mathrm{~mm}$ aggregates against simulated rainfall, \pm standard errors. Description of cropping systems as given in Figs. 1 and 2.

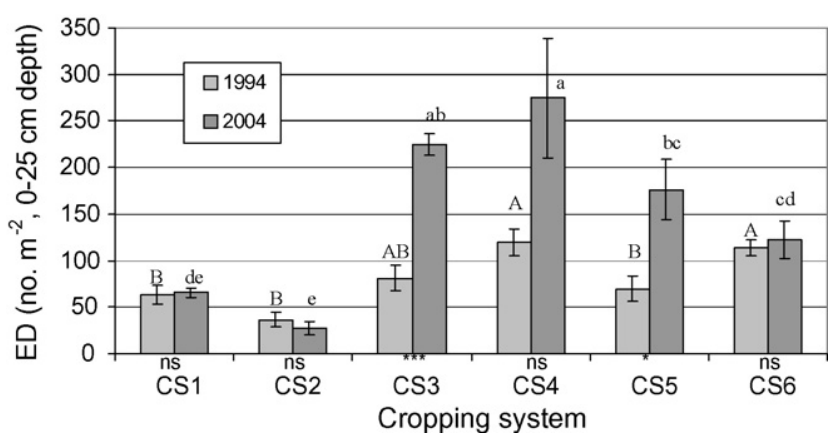

Fig. 7. Earthworm density (ED) in contrasting cropping systems. Description of cropping systems as in Figs. 1 and 2. Different capital letters above the bars indicate significant differences among 1994 values, and different small letters indicate differences among 2004 values. The symbols under the bars indicate significance levels of the changes between 1994 and 2004. The error bars are \pm standard errors.

The density of earthworm channels, pooled over all six systems, had increased by $132 \%$ from 1994 to 2004. The increases were significant in all of the systems with ley (CS3-CS6, Fig. 9). It was significantly higher in 2004 in the organic mixed dairy system (CS6) with $75 \%$ leys (92 channels $\mathrm{m}^{-2}$ ) and in the optimal mixed dairy system (CS4) with $50 \%$ ley $\left(85\right.$ channels $\mathrm{m}^{-2}$ ) than in the other systems. As for other earthworm variables, the lowest channel densities in 2004 were found in the non-organic arable systems (CS1 and CS2), with only 21 and 31 channels $\mathrm{m}^{-2}$, respectively.

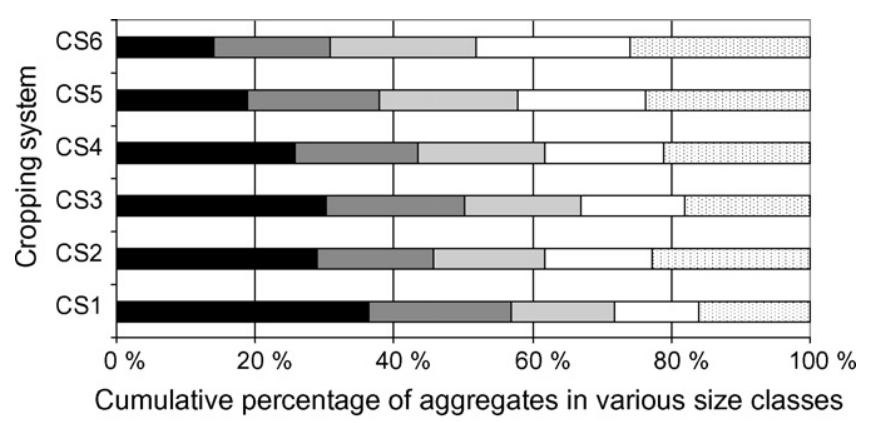

- $>20 \mathrm{~mm} \square 10-20 \mathrm{~mm} \square 6-10 \mathrm{~mm} \square 2-6 \mathrm{~mm} \square<2 \mathrm{~mm}$

Fig. 5. Percentage distribution of aggregates in various size classes (mm) in the topsoil. Description of cropping systems as in Figs. 1 and 2. 


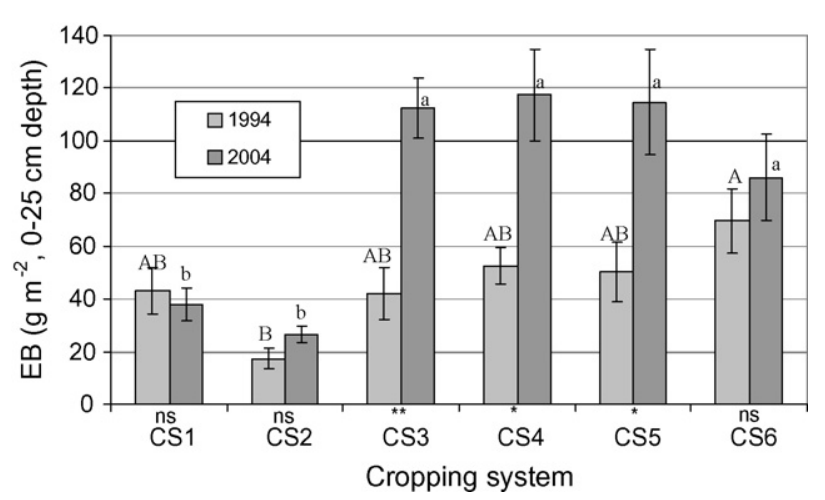

Fig. 8. Biomass of earthworms (EB) in contrasting cropping systems. Description of cropping systems as in Figs. 1 and 2, legends as in Fig. 7.

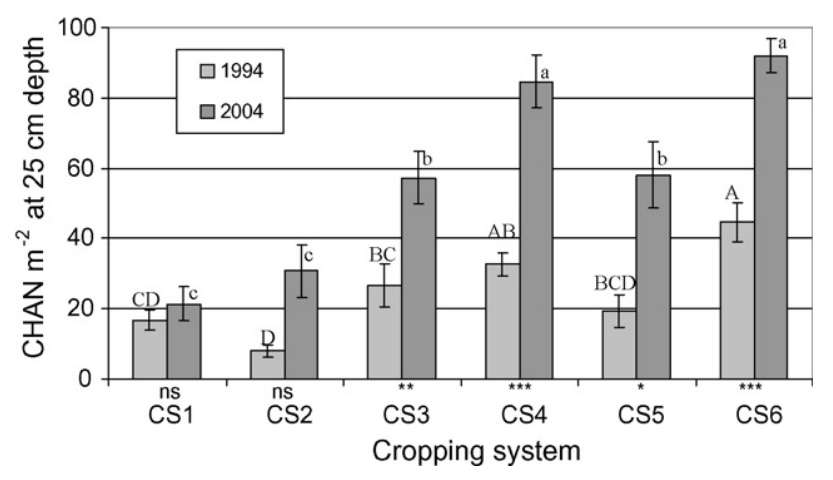

Fig. 9. Numbers of earthworm channels (CHAN) in a horizontal plane, in contrasting cropping systems. Description of cropping systems as given in Figs. 1 and 2, legends as in Fig. 7.

Field worms (Aporrectodea caliginosa), pink worms (Aporrectodea rosea) and night crawlers (L. terrestris), were the dominant species in all six cropping systems, with some differences among systems in their relative abundance (Fig. 10). The conventional arable (CS1) and optimal mixed dairy (CS4) systems had higher proportions of pink worms than the other systems. The arable system with reduced tillage (CS2) had the highest ratio of night crawlers, but the lowest overall number of worms. The number of juvenile earthworms was highest in CS3 and CS4 (data not shown),

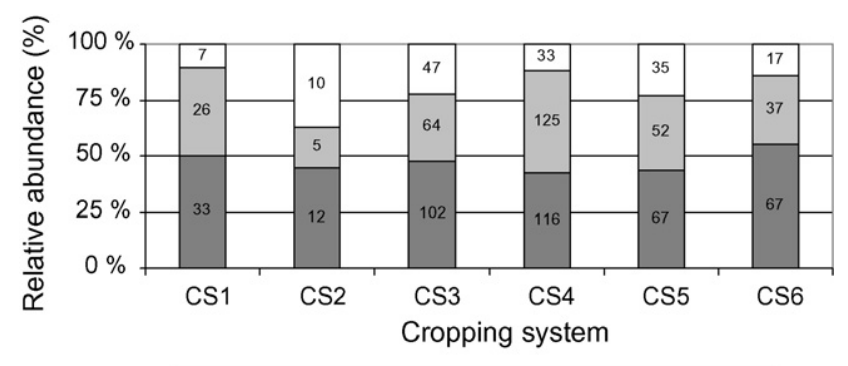

$\square$ Field worm (A. cal.) $\square$ Pink worm (A. ros.) $\square$ Night crawler (L. ter.)

Fig. 10. The relative abundance of earthworm species in each cropping system, 2004. Numbers within columns indicate the density of each species. Description of cropping systems as in Figs. 1 and 2. with noticeably more juvenile pink and field worms in the system with optimal mixed dairy farming (CS4) than in the other mixed dairy systems.

\section{Discussion}

\subsection{Soil structure and organic matter}

Annual ploughing of arable land in the cropping system without either leys or slurry use had negative effects on soil bulk density, the amount of plant available water, aggregate size distribution and aggregate stability. Most of these effects may be associated with the decline in SOM that was measured in this system. These parameters were influenced positively by the inclusion of leys in the rotation, even though slight declines in SOM were found there also, relative to 1988 . The rate of SOM decline in the arable system with annual ploughing was about $2 \%$ per year, relative to the initial level, which is somewhat greater than that measured in a recent survey of SOM declines on arable land in Norway (Riley and Bakkegard, 2006). The possibility of some SOM dilution by deeper ploughing cannot be ruled out, but plough depth was not thought to have increased during this period. Korsaeth and Eltun (in press), who presented nutrient flows for the initial 10-year period of the cropping systems, found that CS1 also had the greatest decline in total soil $\mathrm{N}$.

Replacement of annual ploughing by spring harrowing (CS2) appeared to have a positive effect on SOM and on aggregate stability, but soil porosity nevertheless declined somewhat. Many previous studies in Scandinavia (e.g. Rasmussen, 1999; Riley et al., 1994) have shown that bulk density increases under ploughless tillage soil. This may lead to the impedance of root growth in some cases, particularly on sandy soils (Riley et al., 2005). In the case of the present loam soil, however, the relatively high proportion of large pores $(>30 \mu \mathrm{m})$ suggests that aeration problems are unlikely to arise as a result of this tillage practice.

An incidence of about $50 \%$ leys appears to be sufficient to maintain good soil structure. A tendency was also observed for organic systems to have slightly better structure than non-organic systems with similar amounts of leys. The reason for this is unclear, but it may be that the greater amount of clover present in the organic leys is important, as clover taproots create large biopores and their nutrient-rich leaves stimulate earthworm activity. During the first period of the experiment, the clover content in the conventional (CS4) and the organic (CS5) leys were 12-24\% and 16$63 \%$, respectively (Korsaeth and Eltun, 2000). Favourable effects on soil structure have been reported for several legumes grown together with maize (Latif et al., 1992). On the other hand, Breland (1995) found that ryegrass sown as a catch crop had a better effect on soil structure than did white clover, probably because its roots bound the soil well and provided carbon-rich material that stimulates microbial 
activity. The structure of the soil studied here, a morainic loam, was considered to be good at the start of the experiment. The negative developments observed under conventional arable cropping probably do not represent a major threat to the productivity of this soil. On soils with a less favourable initial structure, such as poorly drained silty clays, such developments might have more serious consequences, both for farmers and for the environment.

\subsection{Earthworm activity}

In accordance with Edwards and Lofty (1977), our results show that leys in the crop rotation increase earthworm density, biomass and the density of channels. Compared to cereals and potatoes, perennial grass and clover produce more organic matter, through decaying roots, foliage and root exudates, that is accessible to the soil fauna. In addition, leys increase soil porosity, as seen in the present investigation, and thus improve earthworm habitats. Leys also increased the activity of worms in deeper soil layers.

Both the incorporation of large amounts of organic matter (CS4) and a longer ley period (CS6) may explain the high density of earthworm channels in these systems. Sveistrup et al. (1997) found that both night crawlers and field worms, both present in these systems, create medium and coarse channels in deeper soil layers.

Earthworm biomass and density were in 2004 higher in the organic arable CS3 than in the other arable systems, in agreement with Scullion et al. (2002). More food was available for earthworms in CS3 than in CS1 and CS2, as large amounts of grass-clover leys were ploughed down at frequent intervals. Until 2000, this system also received some cattle slurry. The inclusion of potatoes in CS1 and CS2 may also have had a negative effect on earthworms. Curry et al. (2002) found that soil cultivation in potato production and potato harvesting reduced earthworm populations to undetectable levels. Furthermore, the long-term use of pesticides in CS1 and CS2 may have influenced the earthworm population negatively. For instance the insecticide alph-cypermethrin (Fastac, used in cereals in CS1, CS2 and CS4), despite its low acute toxicity, has recently shown a high chronic, long-term toxicity to earthworms (Hartnik et al., in press).

It was interesting that the number and activity of earthworms increased noticeably in the organic arable system, CS3, even thought this cereal rotation included just 1 year with grass-clover ley, mown several times. Schmidt et al. (2003) found that the combination of direct drilling and clover understory in cereal systems, increased the earthworm population greatly (50\%). This was primarily because of a favourable input of organic matter in terms of quantity, quality and continuity of food supply throughout the year. Thus, it may be suggested that both clover ley and clover undercrop and 1 year without ploughing in system CS3 benefited earthworms. In the mixed dairy systems (CS4CS6), although herbage was removed, appreciable amounts of organic matter became available to earthworms when the leys were ploughed. In CS6, earthworm sampling was performed in third ley year, so that less organic matter may have been available.

Among the mixed dairy systems, there was a significantly higher density of earthworms in the non-organic system (CS4) than under organic management (CS5 and CS6), but no differences in biomass. These three systems differ less in management and cropping than do the three arable systems. Hence, less difference was to be expected between them in earthworm properties, in accordance with the findings of Scullion et al. (2002). The high number of juveniles in CS4 cannot be fully explained in terms of the amount of cattle slurry used or the larger yields obtained. Far fewer juveniles were found in the most comparable organic fodder system (CS5), despite similar biomass. Pesticide use in CS4 may have altered the food supply for the species involved and/or synchronised reproduction, resulting in a peak of juvenile pink and grey worms in this system.

From past experience (e.g. Ekeberg, 1992; Chan, 2001), increased earthworm populations might have been expected in the arable system with reduced tillage (CS2) compared to that with annual ploughing (CS1). On the contrary, however, we observed a tendency for even lower earthworm density and biomass in the system with only harrowing. Chan (2001) also noted that the density of endogeic species increased with ploughing, whereas the density of night crawlers is often higher without ploughing or harrowing. Although low numbers of night crawlers were found in the two nonorganic arable systems, a higher number was found in CS2 than in CS1, indicating some positive effects of reduced soil tillage on this species. A tendency for more deep-burrowing worms in the absence of ploughing was noted by Riley et al. (2005).

\section{Conclusions}

Soil porosity and humus have decreased since 1988 with declining use of leys, with the most marked reductions in an arable system with annual ploughing. The amount of airfilled pores at field capacity has increased, and the amount of water-filled pores has declined. Annual ploughing has significantly reduced the amount of readily available water.

Aggregate size distribution showed a clear trend towards coarser soil structure with a declining proportion of leys in the rotation. An arable system with reduced tillage had a greater proportion of small aggregates than an arable system with annual ploughing.

Aggregate stability showed clear, significant differences between cropping systems. The system with conventional arable practices had lower stability than all the others, whilst the system with $75 \%$ ley in its rotation and that with reduced tillage had the highest stability.

The presence of grass-clover leys increased earthworm density, biomass and channel density, both in organic and in 
conventional systems. Among the arable systems, the organic system had a higher density and biomass of earthworms as compared to the conventional systems. Among the mixed dairy systems, the optimal non-organic system had the highest density of earthworms in 2004, but there were no differences between these systems in earthworm biomass or density of earthworm channels. Lower earthworm activity was found in the all-arable system with annual rotory harrowing as compared to the system with annual ploughing.

\section{References}

Andersen, C., 1979. The influence of farmyard manure and slurry on the earthworm population (Lumbricidae) in arable soil. In: Dindal, D.L. (Ed.), Soil Biology as Related to Land Use Practices. Proc. 5th Int. Coll. Soil Zool. in Syracuse, US. US-EPA, pp. 325-335.

Ball, B.C., Bingham, I., Rees, R.M., Watson, C.A., Litterick, A., 2005. The role of crop rotations in determining soil structure and crop growth conditions. Can. J. Soil Sci. 85, 557-577.

Ball, B.C., Watson, C.A., Baddeley, J.A., 2007. Soil physical fertility, soil structure and rooting conditions after ploughing organically managed grass/clover swards. Soil Use Manage. 23, 20-27.

Breland, T.A., 1995. Green manuring with clover and ryegrass catch crops undersown in spring wheat: effects on soil structure. Soil Use Manage. $11,163-165$.

Carter, M.R., 2002. Soil quality for sustainable land management: organic matter and aggregation interaction that maintain soil functions. Agron. J. 94, 38-47.

Chan, K.Y., 2001. An overview of some tillage impacts on earthworm population abundance and diversity - implications for functioning in soils. Soil Till. Res. 57, 179-191.

Christensen, B.T., 1990. Long-term changes in soil organic matter of three experiments: effect of fertilization, straw incorporation and crop rotation. In: Decomposition and Soil Organic Matter, Nordic Assoc. Agric. Sci. Seminar Report no. 57, pp. 123-128.

Clements, R.O., Murray, P.J., Sturdy, R.G., 1991. The impact of 20 years' absence of earthworms and three levels of $\mathrm{N}$ fertilizer on a grassland soil environment. Agric. Ecosyst. Environ. 36, 75-85.

CSSC, 1998. The Canadian System of Soil Classification. Ed. Soil Classification Working Group, third ed. Ottawa, $187 \mathrm{pp}$.

Curry, J.P., 1976. Some effects of animal manures on earthworms in grassland. Pedobiologia 16, 425-438.

Curry, J.P., Byrne, D., Schmidt, O., 2002. Intensive cultivation can drastically reduce earthworm populations in arable land. Eur. J. Soil Biol. 38, 127-130.

Cuvardic, M., Tveitnes, S., Krogstad, T., Lombnæs, P., 2004. Long-term effects of crop rotation and different fertilization systems on soil fertility and productivity. Acta Agric. Scand. Sect. B 54, 193-201.

Edwards, C.A., Bohlen, P.J., 1992. The effects of toxic chemicals on earthworms. Rev. Environ. Contam. Toxicol. 125, 23-99.

Edwards, C.A., Lofty, J.R., 1977. Biology of Earthworms, second ed. Chapman and Hall, London, 309 pp.

Edwards, C.A., Lofty, J.R., 1982. Nitrogenous fertilizers and earthworms populations in agricultural soils. Soil Biol. Biochem. 14, 515-521.

Ekeberg, E., 1992. Reduced tillage on loam soil. Soil investigations. Norw. Agric. Res. 6, 223-244.

Eltun, R., 1994. The Apelsvoll cropping system experiment I. Background, objectives and methods. Norw. J. Agric. Sci. 8, 301-315.

Eltun, R., Korsaeth, A., Nordheim, O., 2002. A comparison of environmental, soil fertility, yield, and economical effects in six cropping systems based on an 8-year experiment in Norway. Agric. Ecosyst. Environ. 90, 155-168.
FAO, 1998. World Reference Base for Soil Resources, FAO, Rome, ISBN 92-5-104141-5.

Frampton, G.K., Jansch, S., Scott-Fordsmand, J.J., Rombke, J., van den Brink, P.J., 2006. Effects of pesticides on soil invertebrates in laboratory studies: a review and analysis using species sensitivity distributions. Environ. Toxicol. Chem. 25, 2480-2489.

Green, R.D., Fordham, S.J., 1975. A field method for determining air permeability in soil. MAFF Technical Bulletin 29. In: Soil Physical Conditions and Plant Growth, HMSO, London, pp. 273-287.

Gregorich, E.G., Carter, M.R., Angers, D.A., Monreal, C.M., Ellert, B.H., 1994. Towards a minimum data set to assess soil organic matter quality in agricultural soils. Can. J. Soil Sci. 74, 367-385.

Håkansson, I., Lipiec, J., 2000. A review of the usefulness of relative bulk density values in studies of soil structure and compaction. Soil Till. Res. 53, 71-85.

Hansen, S., Engelstad, F., 1999. Earthworm populations in a cool and wet district as affected by tractor traffic and fertilisation. Appl. Soil Ecol. 13, 237-250.

Hartnik, T., Sverdrup, L., Jensen, J., Toxicity of alphacypermethrin to four terrestrial non-target invertebrates and implications on risk assessment. Environ. Toxicol. Chem., in press.

Kirchmann, H., Persson. J., Carlgren, K., 1994. The Ultuna Long-term Soil Organic Matter Experiment, 1956-1991. Dept. of Soil Sciences, Reports \& Dissertations No. 17, Swedish University of Agricultural Sciences, Uppsala, 55 pp.

Korsaeth, A., Eltun, R., 2000. Nitrogen mass balances in conventional, integrated and ecological cropping systems and the relationship between balance calculations and nitrogen runoff in an 8-year field experiment in Norway. Agric. Ecosyst. Environ. 79, 199-214.

Korsaeth, A., Eltun, R., Synthesis of the Apelsvoll cropping system experiment in Norway ( nutrient balances, use efficiencies and leaching. In: Kirchmann, H., Bergström, L. (Eds.), Organic Farming - Impact on Soil and the Environment, in press.

Korsæth, A., Eltun, R., Nordheim, O., 2001. Forandring av fors $\emptyset$ ksplanen for dyrkingsystemene på Apelsvoll. Grønn forskning 1, 316-323.

Latif, M.A., Mehuys, G.R., Mackenzie, A.F., Alli, I., Faris, M.A., 1992. Effects of legumes on soil physical quality in a maize crop. Plant Soil 140, 15-23.

Lee, K.E., 1985. Earthworms their Ecology and Relationships with Soils and Land Use. Academic press, 389 pp.

Lofs-Holmin, A., 1983. Influence of agricultural practices on earthworms (Lumbricidae). Acta Agric. Scand. 33, 225-234.

Loveland, P., Webb, J., 2003. Is there a critical level of organic matter in the agricultural soils of temperate regions: a review. Soil Till. Res. 70, 1-18.

Ma, W.C., Brussaard, L., de Ridder, J.A., 1990. Long-term effects of nitrogenous fertilizers on grassland earthworms (Oligochaeta Lumbricidae) - their relation to soil acidification. Agric. Ecosyst. Environ. 30, 71-80.

Mäder, P., Fliessbach, A., Dubois, D., Gunst, L., Fried, P., Niggli, U., 2002. Soil fertility and biodiversity in organic farming. Science 296, 1694 1697.

Marinissen, J.C.Y., 1994. Earthworm populations and stability of soilstructure in a silt loam soil of a reclaimed polder in the Netherlands. Agric. Ecosyst. Environ. 51, 75-87.

Njøs, A., 1967. Aggregate stability using artificial rain. West-European methods for soil structure determination. ISSS Working group on soil structure, Ghent, p. 53 (Chapter VI)

Rasmussen, K.J., 1999. Impact of ploughless soil tillage on yield and soil quality: a Scandinavian review. Soil Till. Res. 53, 3-14.

Riley, H. 1988. Cereal yields and soil physical properties in relation to the degree of compactness of some Norwegian soils. Proc. 11th ISTRO Conference, Edinburgh, vol. 1, pp. 109-114.

Riley, H., Bakkegard, M., 2006. Declines of soil organic matter content under arable cropping in southeast Norway. Acta Agric. Scand. Sect. B 56, 217-223.

Riley, H., Eltun, R., 1994. The Apelsvoll cropping system experiment II. Soil characteristics. Norw. J. Agric. Sci. 8, 317-333. 
Riley, H., Børresen, T., Ekeberg, E., Rydberg, T., 1994. Trends in reduced tillage research and practice in Scandinavia. In: Carter, M.R. (Ed.), Conservation Tillage in Temperate Agroecosystems. Lewis Publishers, Boca Raton, pp. 23-45.

Riley, H., Bleken, M., Abrahamsen, S., Bergjord, A.K., Bakken, A.K., 2005. Effects of alternative tillage systems on soil quality and yield of spring cereals on silty clay loam and sandy loam soils in the cool, wet climate of central Norway. Soil Till. Res. 83, 79-93.

Rotich, H.K., Zhang, Z.Y., Zhao, Y.S., Li, J.C., 2004. The adsorption behaviour of three organophosphorous pesticides in peat and soil samples and their degradation in aqueous solutions at different temperatures and $\mathrm{pH}$ values. Int. J. Environ. Anal. Chem. 84, 289-301.

SAS Institute Inc., 1987. SAS/STAT ${ }^{\mathrm{TM}}$ Guide for Personal Computers. SAS Institute Inc., Cary, NC, 1028 pp.

Schjønning, P., Elmholt, S., Christensen, B.T., 2004. Soil quality management - synthesis. In: Schjønning, P., Elmholt, S., Christensen, B.T. (Eds.), Managing Soil Quality: Challenges in Modern Agriculture. CAB International, p. 368.

Schmidt, O., Clements, R.O., Donaldson, G., 2003. Why do cereal-legume intercrops support large earthworm populations? Appl. Soil Ecol. 22, 181-190.

Scullion, J., Neale, S., Philipps, L., 2002. Comparisons of earthworm populations and cast properties in conventional and organic arable. Soil Use Manage. 18, 293-300.

Sims, R.W., Gerard, B.M., 1999. Earthworms. Notes for the Identification of British Species. The Linnean Society of London, London, 157 pp.
Soil Survey Staff, 1998. Keys to Soil Taxonomy, eighth ed. USDA, Washington, $326 \mathrm{pp}$.

Spurgeon, D.J., Svendsen, C., Rimmer, V.R., Hopkin, S.P., Weeks, J.M., 2000. Relative sensitivity of life-cycle and biomarker responses in four earthworm species exposed to zinc. Environ. Toxicol. Chem. 19, 18001808.

Stenrød, M., Eklo, O.M., Charney, M.-P., Benoit, P., 2005. Effect of freezing and thawing on microbial activity and glypgosate degradatin in two Norwegian soils. Pest Manage. Sci. 61, 887-898.

Stenrød, M., Perceval, J., Benoit, P., Almvik, M., Bolli, R.I., Eklo, O.M., Sveistrup, T.E., Kværner, J., 2007. Cold climatic conditions; effects on bioavailability and leaching of the mobile pesticide metribuzin in a silt loam soil in Norway. Cold Regions Sci. Technol., doi:10.1016/j.coldregions.2007.06.007.

Sveistrup, T.E., Haraldsen, T.K., Engelstad, F., 1997. Earthworm channels in cultivated clayey and loamy Norwegian soils. Soil Till. Res. 43, 251262.

Uhlen, G., 1991. Long-term effects of fertilizers, manure, straw and crop rotation on total-N and total-C in soil. Acta Agric. Scand. 41, 119-127.

van Bavel, C.H.M., 1949. Mean weight diameter of soil aggregates as a statistical index of aggregation. Soil Sci. Soc. Am. Proc. 13, 20-23.

Webb, J., Loveland, P.J., Chambers, B.J., Mitchell, R., Garwood, T., 2001. The impact of modern farming practices on soil fertility and quality in England and Wales. J. Agric. Sci. (Camb.) 137, 127-138.

Zicsi, A., 1969. Über die Auswirkung der Nachfrucht und Bodenbearbeitung auf die Aktivität der Regenwürmer. Pedobiologia 9, 141-145. 